\title{
Entrepreneurship and Creative Destruction
}

http://doi.org/10.21272/bel.4(2).102-108.2020

Cathleen Johnson, ORCID: https://orcid.id/0000-0002-9800-2332

Assistant Chair, Economics, West Virginia University, Morgantown, West Virginia, USA

Robert Lusch, ORCID: https://orcid.org/0000-0002-8341-9581

PHD (1949-2017), Editor of "Journal of Marketing", President, American Marketing Association, Dean emeritus, School of Business, University of Oklahoma, Norman, Oklahoma, USA

David Schmidtz, ORCID: https://orcid.org/0000-0003-1598-8915

Kendrick Professor of Philosophy, University of Arizona, Tucson, Arizona, USA

\begin{abstract}
The study deals with reasons for the inefficient operation of the business sector in the economy through the analysis of the relationship between disruptive innovation and creative destruction. The research is carried out in the following logical sequence: the first stage presents William Baumol's hypothesis about why entrepreneurship makes some societies richer and some poorer. There is entrepreneurship in every society, Baumol says, but background circumstances vary, so that entrepreneurship can be productive, but depending on circumstances it also can be unproductive, or even downright destructive. The second stage substantiates the relationship between entrepreneurship, disruptive innovation, and creative destruction; the third stage investigates the role of entrepreneurs in society as integrators of resources and as managers of risk; the last stage defines possible problems in how the business sector functions in society. The study is based on the generalized works shown in the book "Commercial Society" and considers deep but not obvious links between ethics, economics and entrepreneurship. In this work, the ethical question is how people have to live in order to make the world a better place. The economic question is what kind of society makes people willing and able to use their talents in ways that are good for themselves and for their communities. The entrepreneurial question is how people can bring services to the marketplace that can take a community to the next level of prosperity? The article offers tools for evaluating the interconnected effect of three business components: ethics, economics and entrepreneurship. In the framework of entrepreneurship, the authors assess the central role of honesty not only in earning a community's trust, but also in accurate self-assessment. For a corporation to flourish, its key decision makers must be honest with themselves and each other about when their products, supply chains, or marketing strategies are not good enough and need to change. The role of the accountant in obtaining and processing information is likewise substantiated. Accounting calls for sophisticated forms of honesty and integrity: sorting through volumes of data so as to present a truth about a company's cash flow that will not mislead the client.
\end{abstract}

Keywords: Creative Destruction, Entrepreneur, Innovation, Progress, Resource Integrator, Expectations, Value Proposition.

JEL Classification: L26, O31, D80.

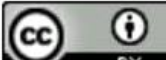

Cite as: Cathleen, J., Lusch, R., Schmidtz, D. (2020). Entrepreneurship and Creative Destruction. Business Ethics and Leadership, 4(2), 102-108. http://doi.org/10.21272/bel.4(2).102-108.2020.

(C) The Authors, 2020. This article is published with open access at Sumy State University.

\section{Introduction}

Our daily dealings with each other are an evolving web of mutual understandings: these come into play every time we stop at a traffic light. We pretty much know what to expect from each other and knowing what to expect enables us to live well together (Schmidtz, 2008). Therefore, we can live as close together as we do, while at the same time having as much room to breathe as we do. Knowing what to expect enables us to adapt to each other 
(Schmidtz, 2010)1 ${ }^{1}$. Not being obliged to conform to expectations is, likewise, an enormous benefit. The two benefits seem mutually exclusive, yet freedom of contract lets us reap both at once. We can rely on being able to go to market and find what we want at an affordable price. We can also expect to find someone rendering obsolete what a few years ago had been cutting-edge technology (Vargo and Lusch, 2014). We test what has not previously been tested, learn from our mistakes, and make progress. We experiment (Hayek, 1945).

However, there is a problem with experiments: they don't always work, and we cannot tell in advance. That is why we need to experiment in the first place (Smith, 2002). Thus, a long-term successful society encourages people not only to experiment but also to shut down experiments when the ideas behind them prove unsound (Mill, 1859). Which parts of our institutional infrastructure encourage experimentation without at the same time preserving bad ideas? Here is one hypothesis that holds in a wide range of cases yet has enough substance to be interesting: the societies that sustain progress are the ones that invite us to experiment without inviting us to be reckless. They hold people responsible for the cost of their own mistakes. One of the most crucial ingredients of commercial progress is that people must be encouraged to invent and push the frontier of technological progress $^{2}$.

\section{Methodology}

This essay summarizes the activity of entrepreneurs in society, reflects on the relationship between disruptive innovation and creative destruction, and suggests the ways that entrepreneurship can go wrong. It revises material from Part VII of Cathleen Johnson, Robert Lusch, and David Schmidtz, Commercial Society: A Primer on Ethics and Economics. The three authors each drew upon decades of teaching in their respective fields of Economics, Marketing, and Moral Philosophy. From their experience in seemingly disparate fields, they each extrapolated lessons and principles: conjectures, that is, about what students need to learn to be successful members of their communities. Given that there is only a human community at the end of the day, not separate communities of ethics, economics, and entrepreneurship. It seemed a fair challenge for the three authors to compare the lessons they were drawing from their respective fields, and check whether the emerging lessons were, after all, coherent. At the end of the day, what we have remains a conjecture, not a testable hypothesis. Yet, we found it remarkable that there is as much congruence in our conclusions as there seems to be.

There is more than a grain of truth in the cliche that "honesty is the best policy." Interestingly, this truth is the truth about moral philosophy. Socrates, one of the Ancient Athenian thinkers whose reflections launched Western Philosophy, is held to have said that the unexamined life is not worth living. The Shakespearean line, "To thine own self be true" picks up on this thought, emphasizing the sense that being honest with oneself is at the heart of the self-examination that goes with living a life worth living.

Even more interestingly, these thoughts from moral philosophy are more than just philosophy. Modern economics explores the wealth-creating properties of society as a cooperative venture for mutual advantage, premised on the idea that traders can acquire information, transmit information, and develop reputations that make it safe to trust what they are saying. Marketing (as our deceased co-author Bob Lusch told us more than once) is grounded in the insight that the truth had better be the best marketing strategy you have. When the truth is not your best advertisement, you need to admit that the world is telling you that what you are selling is not good enough. In a way, the ideas we present here are somewhat testable, insofar as we have seen them emerge from careers teaching in three seemingly unrelated fields.

Three Kinds of Entrepreneur. In the latter half of the $19^{\text {th }}$ century, the North American race to extend their reach to the shores of the Pacific led national governments to invest heavily in transcontinental railroads. Every one of those railroads went bankrupt. The one transcontinental railroad that did not go bankrupt, Great Northern, was the one that declined the subsidies ${ }^{3}$. The problem with subsidies seems obvious in retrospect. Subsidies are meant to incentivize investment behavior. And they work, for better and for worse. They did indeed divert the effort of the railroad magnates into what generates subsidies rather than into what attracts customers. In

\footnotetext{
${ }^{1}$ If some of us choose to become social critics or philosophers instead of inventors and entrepreneurs, so be it. Critics and philosophers serve us well in their own way. They make us pause to reflect on the point of technological progress - and occasionally remind us that there has, after all, been progress. Society was not always the way it is today, nor will it always be as it is today.

${ }^{2}$ Our primary source here is Folsom (2013). See Schmidtz and Brennan (2010).

${ }^{3}$ Few firms face weak competitive intensity; they typically face a lot of competition. This means that competitors are always trying to innovate and outsmart each other with a more appealing value proposition or lower relative resource cost. Here is the problem: Some firms work too hard to develop the perfect new market offering. In striving for perfection, they take too long to get to market with their innovation. In fact, in some firms, accountants slow down new venture projects to a point where products never get to market. Firms need to learn how to commit to improving while not becoming obsessed with perfection.
} 
response to that incentive structure, subsidized railroads reacted as you would expect. Upon learning that subsidies would be a function of number of miles of track laid, railroads maximized the number of miles of track laid, and they laid track wherever track could be laid at the lowest cost. It is how the subsidized railroads came to deserve the nickname of "robber barons." Meanwhile, the unsubsidized Great Northern Railroad was responding to customers, laying the shortest and safest track along routes where there was customer demand.

We might say that there was something entrepreneurial - certain alertness to opportunity - in both business models. But that is to say that whether entrepreneurs are productive or destructive depends on circumstances. Economist William Baumol concludes that there are more entrepreneurs in some societies than in others, but Baumol says that the number of entrepreneurs is not the key to explaining why some societies grow rich while others stay poor. The key variable is whether a society's entrepreneurs are productive, unproductive, or downright destructive. Upon reviewing evidence from ancient Rome, early China, and Medieval and Renaissance Europe, Baumol found enormous variation societies in terms of how entrepreneurs allocate time and resources in a given society (Baumol, 1990).

Simply put, entrepreneurs are entrepreneurial. They go where the opportunity is. If there is money to be made at other people's expense - organized crime, rent-seeking (including campaigning for subsidies), and so on then we'll find entrepreneurs in those roles, doing what entrepreneurs do. If fortunes can be made by inventing new ways of making customers better off, then there, too, we will find entrepreneurs. And when philosophers and moral leaders are careful to distinguish between the two - honoring entrepreneurs who create wealth while damning entrepreneurs who merely capture it - they help to tip entrepreneurial energy in a positive direction.

Disruptive Innovation. Journalists and other social commentators report on the "funerals" of old-fashioned jobs. The standard example is the buggy-whip manufacturers who went out of business as automobiles overtook the horse and buggy. There is never any shortage of companies that fail to adjust to changing times. When the farm became mechanized in the early twentieth century, it was a common fear that farmworkers being displaced would not have jobs. If we could have gone back to a time when the majority of workers were employed in the agricultural sector, and if we had told them that their grandchildren would inhabit a world where less than two percent of the workforce would be in the agricultural sector, they probably would have been seen that as a dystopian nightmare, and would have found it inconceivable that there could ever be that many jobs to be had in cities.

Today we see similar anxieties regarding robotic factories. Will robots displace workers? Of course! The loss of direct factory production jobs is apparent. But the broader view shows a growth in jobs. Jobs in software design, maintenance and repair, computers, and the growth of jobs related to supporting higher levels of sales revenue brought about by lower-cost production are the largely unseen benefits of the shift in these markets. In the recent past, RedBox replaced video rental stores, which had become obsolete.

Few people now mourn the loss of Blockbuster Video. Young people do not even remember it. Blockbuster's time has come and gone. The change was a disruption, but the result was the better services. As the market moves more toward streaming services with Netflix, Hulu, Amazon Prime, and so on, we see the same pattern playing out again. In short, the disrupting and the innovating is fraught with risk. Entrepreneurs take risks. For a time, they will be waves washing over previous generations of innovators, until they too are hit by the next wave. When they create something novel and integrate all the resources needed to offer it to others, there are no guarantees. They often get up early and stay up late, worrying about how to meet payroll, cover household expenses, secure loans, convince investors, and learn and deal with applicable laws and regulations, all the while anticipating that no matter how good their product is, it is just a matter of time before they too get hit by the next wave. It goes with the territory ${ }^{4}$.

Creative Destruction. Disruptive innovation drives what economist Joseph Schumpeter called a perpetual gale of creative destruction. Creative destruction is the process by which innovation disrupts markets and industries, and where the new methods drive out old ones. This driving out of the old is the heart of the dynamics of commercial society. Creative destruction is like a wave. A disruptive innovation starts small then builds to a larger wave, finally crashing down even as another small wave begins to take its place. The process never ends. Disruptive innovation dislodges dominant practices. Skills and jobs become outmoded, waves wash away subsidiary industries until entrepreneur's agency is felt yet again, inventing new skills and new jobs. Strangely enough, many people have no idea how liberating this form of creative destruction has been.

\footnotetext{
${ }^{4}$ These tools for managing risk substantially broke down in the financial crisis following 2007. Lenders were required to have a certain percentage of unqualified borrowers in their portfolios. Mortgage loans requiring no down payment proliferated. Buyers were buying houses as investments rather than as homeshoping to resell a few months later to a "bigger fool" and collect "asset bubble" profits.
} 
Lost jobs make for attention grabbing news. By comparison, new jobs do not grab attention in the same way. They are not much of a story. So, the job creation that comes in the wake of creative destruction is an "unseen benefit" that is at least as important as its more famous cousin, namely the unseen costs that are a justifiably central subject of economic analysis. For example, consider the invention of the automobile around the beginning of the twentieth century. In the United States, the automobile replaced the horse drawn carriage. Before this, the "horsepower" that powered the movement of wagons had literally been supplied by horses: untold thousands of horses in every city, needing to be fed and cared for (and cleaned up after) by untold thousands of workers. With the emergence of the automobile, all these countless numbers of workers had to develop new skills in new industries, including (of course) car manufacturing. Consider the surname "Smith." Variations on the theme of Smith (including the name of one of this essay's co-authors) make up the most common name in Europe, which is a testament to the importance of a blacksmith's job. They were all displaced, by the thousands, but we may judge by how many of their descendants survived that they adapted well.

Tires, batteries, and spark plugs all became industries unto themselves, in service of the automobile. Further, automobiles were expensive and dangerous, which generated new forms of finance and insurance. The automobile also required highways, gas stations, and repair shops. All of this resulted in new institutions and even a new culture. We now call "suburbia" a child of the automobile, as it became possible to plan lives around homes many miles from our workplaces. And let us not forget drive-thru windows. The computer is now emerging as a technology that will change how we live even more than the automobile did. For many of us, computer technology has already made it possible for our place of business to have no specific physical location. Our work can be simply "in the cloud" as they say.

A few years ago, it would not have been possible for employment places to remain functional through the current COVID-19 pandemic, keeping many of our industrial supply chains more or less intact. As we finish this essay in early summer, year 2020, we have yet to know the full measure of this devastating illness. However, as horrible as the pandemic has been, and as horrific as it may yet become, it would have been far worse if it had hit us ten or twenty years ago. Covid-19 is destruction in pure form; it is not the metaphorically "creative" destruction that is an economy's way of redirecting resources away from unproductive uses. But although there is nothing creative about Covid-19 itself, it remains that it is shaping up as a supreme test of humanity's ability to create, innovate, and adapt.

Entrepreneurs as Resource Integrators. While the forces that entrepreneurs unleash result in creative destruction, entrepreneurs are themselves resource integrators at heart (Lusch and Webster, 2011). Creating is the activity in the foreground. Destruction is in the background. The destruction consists not in acts of violence but in once-viable businesses concluding that they should not need to work that hard or think that hard; they should not be subject to a constant pressure to revitalize and reinvent their business so as to stay ahead of customers' changing needs (Vargo and Lusch, 2008). When we hear the word "entrepreneur," we think of people like Henry Ford, Sam Walton, Oprah Winfrey, Steve Jobs, or Martha Stewart. But most entrepreneurs are not famous. They are everywhere, and they are the engines of economic growth.

Entrepreneurs identify opportunities to serve the needs of others. Entrepreneurs are on the lookout for new ideas and new resources, and unfamiliar uses for familiar resources. Entrepreneurs ask how they might access and integrate all the resources needed to offer customers a service that customers will value. Entrepreneurs take on a risk that often others are not willing or able to assume. These are distinctive characteristics of an entrepreneur. Any business enterprise can have an entrepreneurial orientation or spirit. When all is going well, entrepreneurial firms: (1) regularly explore new opportunities to better serve customers, (2) are open minded regarding the nature of resources and how to obtain them, (3) identify ways to integrate resources in creative ways to operate more effectively, and, (4) acknowledge and accept the associated risks. To avoid misunderstanding, we say these things to describe entrepreneurship, not glorify it. (Our final section reflects on failures of entrepreneurship.) The unproductive and downright destructive kinds of entrepreneur described by Baumol are out there. They will be inventing creative ways to manage risk. And when it becomes possible to manage risk by transferring risk to innocent third parties, so that hapless taxpayers become the last-resort underwriters of businesses deemed "too big to fail" then we are again in an age of robber barons. Risk management will always be an ongoing key to the successful business. That will not change. The key variable regarding economic progress is the extent to which risk and cost can be managed by externalizing them passing them along to innocent bystanders.

Entrepreneurs as Risk Managers. In circumstances where the cost of taking risks is internalized, we will observe that entrepreneurs who last tend not to be reckless. The risks they take are calculated. Going in, they want to be sure that they will be able to handle the downside, and likewise sure that the likely upside is worth 
the risk. There is a method to how they behave. All entrepreneurs deal with incomplete information about customers, technologies, and other external factors. They never know for sure how potential customers will respond to new possibilities, or whether the cost of delivering a promising new technology will drop far enough to make the new technology commercially viable (Vargo and Lusch, 2014). Why is there so much risk and uncertainty in an entrepreneur's world in the first place? Consider that chess is a simple game. There are only a handful of rules, and they are well-defined. Even so, the game involves more than one player. That alone makes the game of chess a radically uncertain domain. Now imagine there are millions of other players, and some of the squares on the board are so far away that the best you can do is look them up on a map. Imagine further that the rules are somewhat loose, and nothing is stopping the more creative players from inventing new ways of moving around the board.

Science can study this world, and identify patterns, but cannot make this world highly predictable. If you knew everything there is to know about stock markets, you still would only be able to guess what level the NASDAQ will be at an hour after it opens for trading next Tuesday morning. And yet, the science and the logic of economics can tell you some things. Economic logic can tell you that if you increase the money supply, prices will rise, all other things being equal. But it cannot tell you that other things will, in fact, be equal. As each entrepreneur commits resources and makes his or her next move, thousands or millions of others are doing likewise. The market is inherently dynamic and uncertain. Economics cannot be an exact science, nor should we expect it to be. The world in which entrepreneurs live is substantially predictable in many ways, but every day brings relevant and sometimes costly surprises.

To give a small but significant example of an innovation in developing tools for managing risk, traders in Amsterdam invented calls and puts in the early seventeenth century. A call is an option to buy, and a put is an option to sell a stock or commodity at a specified price. In other words, suppose you own shares in a company where the shares are valued at $\$ 75$. You might give your agent a standing order to buy more shares in the company if the price falls to $\$ 50$, and perhaps it will also sell your shares in the company if the price ever rises to $\$ 100$. The conditional order to buy at $\$ 50$ is a call, and the conditional order to sell at $\$ 100$ is a put. Calls and puts give traders tools for managing investment risk in general and market volatility in particular.

To give another example, the concept of interest on loans was a Mesopotamian invention of around $3000 \mathrm{BC}$. It is easily among the most liberating innovations in human history, despite historically ubiquitous hostility to the concept of usury. In particular, because of the invention of mortgage lending, young people don't have to amass a small fortune to be able to buy a house. Older people don't need to amass a larger fortune to be able to afford to build an apartment building so that young renters can have somewhere to live while they are saving up for a down payment. Instead, a would-be buyer can borrow most of the purchase price and repay that amount over a period of years. Of course, in order to make it feasible for borrowers to be able to find investors willing to finance most of a real estate purchase, there had to be a return on investment. The concept of repaying a loan with interest was a creative way of generating a return on investment that everyone could live with, and that in particular could result in investment capital becoming widely available to qualified borrowers. Now, the idea of being a "qualified" borrower is the secret to managing risk in the lending industries. In the case of real estate, buyers who want to qualify for a loan must be able to document a history of successfully managing credit obligations. They must substantially share in the risk by putting up their own capital in the form of a down payment. And they must be willing to use the purchased real estate as collateral to secure the loan in case they end up being unable to repay it ${ }^{1}$ (Schmidtz and Brennan, 2010).

\section{Conclusions}

Three Big Errors. Surviving as a business in a competitive environment requires that a firm continuously innovate. This innovation can be focused on developing a relatively more appealing value proposition and developing an advantage in relative resource cost.

\section{A) Technology Focus}

Many firms, especially those run by engineers, are not so much customer-centric as technology-centric. They focus on how new technologies can dramatically improve a market offering. There can be a tendency to overengineer the product to enable it to do too many things. This sounds reasonable, but customers may neither need nor want extreme technological enhancements. Engineers need to learn to be customer focused. Engineers can also understand how customers use products and understand that customers can be a valuable source of new product ideas. 


\section{B) Failed Value Proposition: A Bigger Error}

A more important kind of failure lies in being firm-centric rather than customer-centric. A firm does not provide potential customers with value so much as a value proposition. A value proposition is a promise of some benefit associated with a market offering. Sellers compete, and potential customers confront a range of competing value propositions. Sellers enhance a value proposition by moving it beyond mere price. A brand image can differentiate a firm's product from those of competitors. Branding protects a seller to some degree from price competition, and it may also provide more pricing flexibility. If value propositions are effective, customers obtain value not only from a tangible product but also from an extended product that embodies many intangibles. Often, however, the value proposition that a firm develops is not in tune with what customers want. A firm can overthink about what it does best, and too little about how its market offering must either relieve customers of work or enable customers to achieve things they could not otherwise achieve. A good value proposition creates a sort of glue that binds the customer to the firm's offering. A compelling value proposition invites engagement from the customer.

\section{C) Moral Error: The Biggest Error}

We have so far discussed risk on the premise that the cost and risk of entrepreneurship is internalized. In effect, entrepreneurs pay for their own mistakes. When this premise is incorrect, we are in a radically different situation and entrepreneurship predictably will have radically different results. As explained earlier, down payments in the mortgage lending industry take the risk involved in being a lender and make it incentive compatible. By contrast, the business model of the robber barons is predicated on maximizing the cost to "investors" who are conscripted as investors by virtue of being citizens. Politicians decide how much to charge taxpayers, who cannot easily decline the "offer." Meanwhile, the robber barons want to maximize rather than minimize the cost to taxpayers. They are not trying to improve their value proposition. Quite the opposite. They want to maximize the cost of their product, because that cost is externalized, and is indeed a stream of cash that flows directly into their pockets in the form of tax-funded subsidies.

From a social perspective, subsides reward mistakes. Even worse, subsidies lock in mistakes. Subsidized manufacturers go on producing products that customers don't want, when the gale of creative destruction should be redirecting resources into manufacturing that serves a purpose - a purpose that customers have. Creative destruction is a process by which a society avoids locking up scarce resources in zombie projects that no longer serve customers. There is a kind of cynicism that treats morality as if it were a luxury that hardnosed entrepreneurs would not value and would not be able to afford even if they cared about it. Cynics want to think of themselves as the realists, but cynics are losers as a matter of observation. The reality is that the truth had better be your best marketing tool. If the truth won't sell your product, then you need a better product.

Durably successful entrepreneurs understand the basic value proposition. They are political animals, so they understand that success in life is a matter of building a place for themselves in a community of political animals. They want something from other people. More than anything else, they want to be wanted. They want others to appreciate what they do to be of service. They do not want it to be simply their false facades that other people mistakenly esteem. They want people to know who they were. Their dream is to be heroes, not villains who didn't get caught. Sooner or later, they all realize that what they want out of life is to know (and to know that their children know) that it was good that they were here. Their community was better off with them than without them. Learning too late that this the point of it all is the biggest mistake a person can make.

\section{Acknowledgement}

This essay substantially revises material from Part VII of Cathleen Johnson, Robert Lusch, and David Schmidtz, Commercial Society: A Primer on Ethics and Economics.

\section{References}

1. Baumol, William J. (1990). Entrepreneurship: Productive, Unproductive, and Destructive. Journal of Political Economy, 98, 893-921. DOI: 10.1086/261712.

2. Blackstone, W. (1979). Commentaries on the Laws of England [1765]. (Chicago: University of Chicago Press). Available at: https://oll.libertyfund.org/titles/blackstone-commentaries-on-the-laws-of-england-infour-books-2-vols.

3. Calabresi, Guido and Melamed, A. Douglas. (1972). 'Property Rules, Liability Rules and Inalienability: One View of the Cathedral (link is not found), Harvard Law Review, 85, 1089-1128. Available at: https://onlinelibrary.wiley.com/doi/10.1002/9780470752135.ch3. 
4. Demsetz, H. (1967). Toward a Theory of Property Rights. American Economic Review (Papers \& Proceedings), 57, 347-59. DOI: https://doi.org/10.1057/9780230523210_9.

5. Ellickson, Robert C. (1991). Order Without Law: How Neighbors Settle Disputes (Cambridge: Harvard University Press). Available at:

https://www.amazon.com/gp/product/0674641698/ref=as_li_qf_sp_asin_il_tl?ie=UTF8\&tag=bleedheartli b-20.

6. Ellickson. Robert C. (1993). Property in Land. Yale Law Journal, 102, 1315-400. Available at: https://digitalcommons.law.yale.edu/fss_papers/411/.

7. Folsom, B. (2013). The Myth of the Robber Barons (Herndon: Kirby Center). ISBN: 978-0963020314,

8. Friedrich Hayek (September 1945). The Use of Knowledge in Society. The American Economic Review 35(4), 519-530. DOI: 10.1142/9789812701275_0025.

9. Grotius, H. (2005). Rights of War and Peace [1625], (London: Elibron). Available at: https://oll.libertyfund.org/titles/grotius-the-rights-of-war-and-peace-1901-ed.

10.Hardin, G. (1968). The Tragedy of the Commons, Science, 162, 1243-48. Available at: https://science.sciencemag.org/content/162/3859/1243.full.

11. Hohfeld, W. (1964). Fundamental Legal Conceptions, [1913 and 1917], New Haven: Yale University Press, 114p. Availabe at: https://www.amazon.com/Fundamental-Conceptions-WESLEY-NEWCOMBHOHFELD/dp/B0000CM549.

12.Lewis, J. (1888). Law of Eminent Domain, Chicago: Callaghan and Co., 880 p.

13.Locke, J. (1960). Second Treatise of Government. [1690] P. Laslett (ed.), (Cambridge: Cambridge University Press). Available at: https://oll.libertyfund.org/titles/locke-the-two-treatises-of-civilgovernment-hollis-ed.

14.RF Lusch, FE Webster Jr. (2011). A stakeholder-unifying, cocreation philosophy for marketing. Journal of Macromarketing, 31, 129-34. DOI: 10.1177/0276146710397369.

15.Johnson, Cathleen, Robert Lusch, and David Schmidtz (2019). Commercial Society: A Primer on Ethics and Economics, London: Rowman \& Littlefield. Available at: https://www.rowmaninternational.com/book/commercial_society/3-156-d48fad46-16df-4657-b11a84ef2f49fe97.

16.Mill, J. S. (1859). On Liberty. DOI: 10.1007/978-1-349-81780-1_1.

17.Rose, C. (1985). Possession as the Origin of Property, University of Chicago Law Review, 52, 73-88. DOI:10.1007/978-1-349-81780-1_1.

18.Rose, C. (1986). The Comedy of the Commons: Custom, Commerce, and Inherently Public Property. University of Chicago Law Review, 53, 711-87. Available at: https://digitalcommons.law.yale.edu/fss_papers/1828/.

19.Schmidtz, D. (2008). Person, Polis, Planet: Essays in Applied Philosophy, New York: Oxford University Press, 267 p. Available at: https://www.amazon.com/Person-Polis-Planet-AppliedPhilosophy/dp/0199861706.

20.Rose, C. (1994). Property and Persuasion, Boulder: Westview. Chapter 1. Available at: https://www.law.yale.edu/sites/default/files/documents/pdf/Faculty/propertypersuasion.pdf.

21.Schmidtz, D. \& Jason B. (2010). A Brief History of Liberty. London: Blackwell. DOI: $10.1002 / 9781444318289$.

22.Schmidtz, D. (2010). Property and Justice. Social Philosophy and Policy, 27, 79-100. https://doi.org/10.1017/S0265052509990045.

23.Schmidtz, D. (2011). Property. Oxford Handbook: History of Political Theory, ed. G. Klosko (New York: Oxford University Press), 599-610. Available at:

https://freedomcenter.arizona.edu/sites/freedomcenter.arizona.edu/files/7\%20Property\%20Klosko\%2020 18_0.pdf.

24.Schumpeter, J. (1942). Capitalism, Socialism, \& Democracy. New York: Harper. Chapter 3, pp. 38-47. Available at: https://eh.net/book_reviews/capitalism-socialism-and-democracy/.

25.Smith, V. (2002). Constructivist and Ecological Rationality in Economics. Prize Lecture. Available at: https://www.nobelprize.org/uploads/2018/06/smith-lecture-2.pdf.

26.Vargo, S. L., \& Lusch, R. F. (2014). Inversions of service-dominant logic. Marketing Theory, 14(3), 239-248. https://doi.org/10.1177/1470593114534339.

27.Vargo, S. L., Lusch, R. F. (2008). Service-dominant logic: continuing the evolution. Journal of the Acad. Mark. Sci. 36, 1-10. https://doi.org/10.1007/s11747-007-0069-6. 